\title{
Requirements for occupational medicine training in Europe: a Delphi study
}

\author{
E B Macdonald, K A Ritchie, K J Murray, W H Gilmour
}

\begin{abstract}
Objectives-To identify the common core competencies required for occupational physicians in Europe.

Method-A modified Delphi survey was conducted among members of the European Association of Schools of Occupational Medicine (EASOM), the Occupational Medicine Section of the Union of European Medical Specialities (UEMS), and of the European Network of Societies of Occupational Physicians (ENSOP). An initial questionnaire based on the training syllabus of the United Kingdom Faculty of Occupational Medicine was circulated and respondents were asked to rate the importance of each item. The results were discussed at a conference on the subject of competencies. A further questionnaire was developed and circulated which asked respondents to rank items within each section.
\end{abstract}

Results-There was a $74 \%$ response in the first round and an $80 \%$ response in the second. Respondents' ratings from most important to least important were; occupational hazards to health, research methods, health promotion, occupational health law and ethics, communications, assessment of disability, environmental medicine, and management. In the second round, among those topics ranked most highly were; hazards to health and the illnesses which they cause, control of risks, and diagnoses of work related ill health. Topics such as principles of occupational safety and selection of personal protection equipment were of least importance. Although the assessment of fitness was regarded as important, monitoring and advising on sickness absence were not highly rated. Management competency was regarded as of low importance. Conclusion-This survey identified that respondents had traditional disease focused views of the competencies required of occupational physicians and that competencies were lagging behind the evolving definition of occupational health.

(Occup Environ Med 2000;57:98-105)

Keywords: competencies; Delphi study; occupational medicine training

One of the first to describe the competencies required of occupational physicians was Bernadino Ramazzini when he emphasised the importance of the occupational history: "and to the questions recommended by Hippocra- tes, he should ask one more "what occupation does he follow?" $1 \mathrm{He}$ also established the principles of risk assessment when he wrote "the physician should not think it unbecoming to visit the lowliest workshops and study the mysteries of the mechanic arts."

The International Labour Organisation (ILO) and the World Health Organisation (WHO) have had a common definition of occupational health since the formation of the ILO/WHO Joint Committee on Occupational Health in 1950 . This was revised in $1985^{2}$ to reflect the increasing emphasis on occupational health promotion presented in the WHO Global strategy for health for all by the year 2000. The definition was further broadened in May 1996 at the 49th World Health Assembly to the following: "the overall promotion of health and workability for all employees".

These revisions have resulted in a changing need for occupational health to encompass health promotion as well as health protection, an active improvement of the working environment, and the development of work organisation and culture to support health and safety at work. In turn this has led to changing requirements in the competencies which occupational physicians need to have. Additional influences are also developments within the commercial world, with industry increasingly becoming international and the widespread application of quality management principles to all industrial activities.

Across the European Union fundamental principles of harmonisation and free movement of labour and capital have led to a common basis for health and safety legislation and also the training and mutual recognition of medical specialists. Reference to competent people also occurs within the legislation of individual countries and is often used within United Kingdom legislation. However, legislative bodies, while using the word competent, have not defined what is meant by competent when referring to trained occupational physicians.

The curricula of specialist training within countries of the European Union have thus been underpinned by general principles, the ILO, WHO agreements, and more recently, by EU legislation. However, within Europe it has been clear that the emphasis of training, and indeed the roles of occupational physicians, have varied considerably depending on historical practice and local legislation. For example, some countries do not have trained occupational health nurses, whereas in other countries this related discipline is highly developed. 
Table 1 Definitions

Knowledge Specific information about a subject

Experience Direct personal participation or observation

Competence The condition of being capable; ability; the state of being legally competent or qualified

Table 2 Distribution of responses by country

\begin{tabular}{lclc}
\hline Country & $\begin{array}{l}\text { Respondents } \\
(n)\end{array}$ & Country & $\begin{array}{l}\text { Respondents } \\
(n)\end{array}$ \\
\hline Austria & 2 & Latvia & 1 \\
Belgium & 3 & Lithuania & 2 \\
Bulgaria & 2 & Norway & 4 \\
Czech Republic & 6 & Portugal & 4 \\
Denmark & 2 & Russia & 1 \\
Finland & 1 & Slovak Republic & 3 \\
France & 2 & Spain & 1 \\
Germany & 10 & Sweden & 3 \\
The Netherlands & 3 & Switzerland & 2 \\
Hungary & 1 & Turkey & 1 \\
Ireland & 2 & United Kingdom & 4 \\
Italy & 5 & Total & 65 \\
\hline
\end{tabular}

In response to these changes three European networks of occupational physicians have developed. The first of these was the European Association of Schools of Occupational Medicine (EASOM), followed by the Occupational Medicine Section of the Union of European Medical Specialties (UEMS) and the European Network of Societies of Occupational Physicians (ENSOP). The UEMS has produced European Charters on the training of medical specialists and working groups are active in the production of European standards and qualifications and have access to the political framework in Europe through the Comite Permanent of the European Union. The EASOM and ENSOP are professional networks developed in response to professional initiatives and have no formal mandates. Within all these organisations discussions on the required competencies and activities of occupational physicians has been a major topic.

In early 1997 the Board of the EASOM recommended that the common core competencies required of occupational medicine specialists across Europe should be drawn up. It was decided therefore that a survey would be conducted among the members of EASOM, UEMS, and ENSOP. Membership of EASOM is open to institutions which provide postgraduate training resulting in a recognised specialist qualification in occupational medicine. The UEMS occupational medicine section comprises two people from each member state elected through the professional associationfor example, the British Medical Association in the United Kingdom. One representative must be an academic and the other a practitioner. The ENSOP is comprised of two nominated

Table 3 Mean scores of topic areas

\begin{tabular}{llll}
\hline & \multicolumn{2}{l}{ Mean scores } & \\
\cline { 2 - 4 } & Knowledge & Experience & Competence \\
\hline Occupational hazards to health & 4.4 & 4.2 & 4.5 \\
Research methods & 4.3 & 4.0 & 4.0 \\
Health promotion & 4.1 & 3.6 & 3.6 \\
Occupational health law and ethics & 4.0 & 4.0 & 4.2 \\
Communications & 4.0 & 4.0 & 4.2 \\
Assessment of disability & 3.7 & 3.6 & 3.9 \\
Environmental medicine & 3.4 & 3.5 & 3.5 \\
Management & 3.3 & 3.3 & 3.6 \\
\hline
\end{tabular}

members from each of the national societies of occupational medicine within the European Union. Opinions could be then obtained from this survey population of representatives of academics and practitioners in occupational medicine. A form of the Delphi process was used in an attempt to derive consensus of these opinions.

\section{Method}

The survey took the form of a Delphi study with a questionnaire being developed, circulated, and modified and then the modified version redistributed to the participants. The Delphi technique has been used in several different ways relating to the problem being approached and group responding. ${ }^{3}$ It has been successfully used in the past to collate the opinions of occupational physicians. ${ }^{5-7}$ In the study reported here an existing list of competencies required of specialists in occupational medicine was circulated as a questionnaire. This list of subjects was derived from the United Kingdom Faculty of Occupational Medicine training regulations which describes eight basic competencies. ${ }^{8}$ These competencies are further divided into three areas-namely, knowledge, experience, and competence. For the purposes of this study, these terms have been defined in table 1 .

The questionnaire was distributed to all members of EASOM, UEMS, and ENSOP included in mailing lists available at the time. The mailing lists identified 34 EASOM, 23 UEMS, and 32 ENSOP representatives. Altogether 89 questionnaires were distributed in the initial circulation and respondents were asked to indicate the relative importance of the items and to add to the lists where appropriate. Returned questionnaires were analysed and preliminary results were communicated at a conference exploring the topic area and held in Glasgow in April 1997. ${ }^{9}$ During this conference all delegates were given copies of the first questionnaire. This conference also explored and compared the description of competencies of national standard setting bodies throughout Europe, the United States, and Australasia.

A second questionnaire was then produced including items added by first round respondents and conference delegates. No items were removed from the lists but all new topics suggested by respondents were included. The resulting questionnaire retained the same structure of 24 sections with a total of 160 items. This second questionnaire was then circulated again to 87 members of the organisations involved for whom current addresses could be obtained. In this instance respondents were asked to place each of the items in rank order within the 24 sections. The item considered most important was given a rank of 1 , next most important 2 and so on. It was not permitted to give 2 items in a subsection the same score. Additional items were not invited in this round although a section for remarks was included. 
Table 4 Results of Wilcoxon signed ranks tests for knowledge subsection with mean scores of subject areas indicated

\begin{tabular}{|c|c|c|c|c|c|c|c|c|}
\hline & $\begin{array}{l}\text { Occupational } \\
\text { hazards to } \\
\text { health }\end{array}$ & $\begin{array}{l}\text { Research } \\
\text { methods }\end{array}$ & $\begin{array}{l}\text { Health } \\
\text { promotion }\end{array}$ & $\begin{array}{l}\text { Occupational } \\
\text { health law and } \\
\text { ethics }\end{array}$ & Communications & $\begin{array}{l}\text { Assessment of } \\
\text { disability }\end{array}$ & $\begin{array}{l}\text { Environmental } \\
\text { medicine }\end{array}$ & Management \\
\hline & 4.35 & 4.30 & 4.14 & 3.96 & 3.95 & 3.73 & 3.39 & 3.30 \\
\hline $\begin{array}{l}\text { Occupational hazards to health } \\
4.35\end{array}$ & & NS & $\star$ & $\star \star \star \star$ & $\star \star \star$ & $\star \star \star$ & $\star \star \star$ & $\star \star \star \star$ \\
\hline $\begin{array}{l}\text { Research methods } \\
4.30\end{array}$ & & & NS & $\star \star \star$ & $\star \star \star \star$ & $\star \star \star \star$ & $\star \star \star$ & $\star \star \star$ \\
\hline $\begin{array}{l}\text { Health promotion } \\
4.14\end{array}$ & & & & * & * & $\star \star \star \star$ & $\star \star \star \star$ & $\star \star \star \star$ \\
\hline $\begin{array}{l}\text { Occupational health law and ethics } \\
3.96\end{array}$ & & & & & NS & * & $\star \star \star \star$ & $\star \star \star \star$ \\
\hline $\begin{array}{l}\text { Communications } \\
3.95\end{array}$ & & & & & & * & $\star \star \star \star$ & $\star \star \star \star$ \\
\hline $\begin{array}{l}\text { Assessment of disability } \\
3.73\end{array}$ & & & & & & & * & $\star \star \star$ \\
\hline $\begin{array}{l}\text { Environmental medicine } \\
\text { 3.39 } \\
\text { Management } \\
3.30\end{array}$ & & & & & & & & NS \\
\hline
\end{tabular}

${ }^{\star} \mathrm{p}<0.05 ;{ }^{\star \star} \mathrm{p}<0.01 ;{ }^{\star \star \star} \mathrm{p}<0.001$ row item higher $v$ column.

\section{Results}

ROUND 1

Of 88 questionnaires sent out, 65 responses ( $74 \%$ response rate) were received within the given time limit. These eligible responses represented 23 countries (table 2). Questionnaires were not received in time from Poland and there were no questionnaires returned from Croatia, Greece, Luxembourg, Romania, or Ukraine.

The number varied from country to country depending on the nationality of the various committee members, and subsequent local distribution of the questionnaire led to additional responses from some countries-for example, 10 from Germany.

Respondents were asked to give each item on the list a separate score from 0 to 5 relating to the importance of the subject. A score of 0 indicated that the item was not necessary, 1 it was of minimal importance, and 5 it was most important or essential. Results were entered into a database package on a personal computer and analysed with the statistical package for

Table 5 Results of Wilcoxon signed ranks tests for experience subsection with mean scores of subject areas indicated

\begin{tabular}{|c|c|c|c|c|c|c|c|c|}
\hline & $\begin{array}{l}\text { Occupational } \\
\text { hazards to } \\
\text { health }\end{array}$ & Communications & $\begin{array}{l}\text { Research } \\
\text { methods }\end{array}$ & $\begin{array}{l}\text { Occupational } \\
\text { health law and } \\
\text { ethics }\end{array}$ & $\begin{array}{l}\text { Assessment of } \\
\text { disability }\end{array}$ & $\begin{array}{l}\text { Health } \\
\text { promotion }\end{array}$ & $\begin{array}{l}\text { Environmental } \\
\text { medicine }\end{array}$ & Management \\
\hline $\begin{array}{l}\text { Occupational hazards to health } \\
4.18\end{array}$ & 4.18 & $\begin{array}{l}4.00 \\
\text { NS }\end{array}$ & $\begin{array}{l}4.00 \\
\text { NS }\end{array}$ & $\begin{array}{l}3.95 \\
\text { NS }\end{array}$ & $\begin{array}{l}3.63 \\
\star \star \star\end{array}$ & 3.60 & $\begin{array}{l}3.50 \\
\star \star \star\end{array}$ & $\begin{array}{l}3.25 \\
\star \star \star\end{array}$ \\
\hline $\begin{array}{l}\text { Communications } \\
4.00\end{array}$ & & & NS & NS & $\star \star \star$ & $\star \star$ & $\star \star \star$ & $\star \star \star \star$ \\
\hline $\begin{array}{l}\text { Research methods } \\
4.00\end{array}$ & & & & NS & $\star \star$ & $\star$ & $\star \star$ & 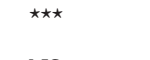 \\
\hline $\begin{array}{l}\text { Occupational health law and ethics } \\
3.95\end{array}$ & & & & & $\star \star$ & NS & $\star \star$ & NS \\
\hline $\begin{array}{l}\text { Assessment of disability } \\
3.63\end{array}$ & & & & & & NS & NS & $\star \star \star \star$ \\
\hline $\begin{array}{l}\text { Health promotion } \\
3.60 \\
\text { Environmental medicine } \\
3.50 \\
\text { Management } \\
3.25\end{array}$ & & & & & & & NS & 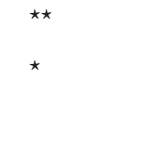 \\
\hline & $\begin{array}{l}\text { Occupational } \\
\text { hazards to }\end{array}$ & $\begin{array}{l}\text { Occupational } \\
\text { health law and }\end{array}$ & & Research & Assessment of & & Health & Environmental \\
\hline & health & ethics & Communications & & disability & Management & promotion & \\
\hline & 4.46 & 4.23 & 4.18 & 4.01 & 3.87 & 3.64 & 3.58 & 3.54 \\
\hline $\begin{array}{l}\text { Occupational hazards to health } \\
4.46\end{array}$ & & $\star$ & $\star \star \star \star$ & $\star \star \star \star$ & $\star \star \star$ & $\star \star \star$ & $\star \star \star$ & $\star \star \star$ \\
\hline $\begin{array}{l}\text { Occupational health law and ethics } \\
4.23\end{array}$ & & & NS & * & $\star \star$ & $\star \star \star$ & $\star \star \star$ & $\star \star \star$ \\
\hline $\begin{array}{l}\text { Communications } \\
4.18\end{array}$ & & & & $\star \star$ & $\star \star$ & $\star \star \star$ & $\star \star \star \star$ & $\star \star \star$ \\
\hline $\begin{array}{l}\text { Research methods } \\
4.01\end{array}$ & & & & & NS & $\star \star \star \star$ & $\star \star$ & $\star \star$ \\
\hline $\begin{array}{l}\text { Assessment of disability } \\
3.87\end{array}$ & & & & & & $\star$ & NS & $\star$ \\
\hline $\begin{array}{l}\text { Management } \\
3.64\end{array}$ & & & & & & & NS & NS \\
\hline $\begin{array}{l}\text { Health promotion } \\
3.58\end{array}$ & & & & & & & & NS \\
\hline $\begin{array}{l}\text { EnvironmentalmMedicine } \\
3.54\end{array}$ & & & & & & & & \\
\hline
\end{tabular}


Occupational hazards to health:

Section 1A, knowledge:

Hazards to health in the workplace and the illnesses which they cause

Evaluating and controlling risk from hazards

Principles of toxicology, occupational hygiene, and ergonomics

Clinical features and investigation of occupational disease

Sources of information in occupational health hazards

Principles of health surveillance

Occupational health standards

Biological monitoring

Principles of occupational safety

Emergency treatment of injury at work

Section 1B, experience:

Assess and advise on range of working environments

Surveillance of workers at risk of occupational injury and disease

Differential diagnosis of work related ill health

Liaison with other specialists on workplace assessment

Management of workers developing work related disease or injury

Use of basic occupational hygiene equipment

Experience in general clinical toxicology

Supervise health and safety training

Use of ILO classification of radiographs

Section 1C, competence:

Undertake workplace assessments and advise on control measures

Diagnose work related ill health

Take a clinical history and examination proficiently

Organise appropriate investigations for diagnosis of occupational disease

Recognise need for specialist assessment of environment

Organise health surveillance for workers exposed to occupational hazards

Advise on provision of first aid facilities

Select appropriate personal protective equipment

Advise on the use of equipment and the planning of working environment

Advise on the introduction of new working systems and techniques

Assessment of disability and fitness for work:

Section 2A, knowledge:

Principles of assessing fitness for work

Statutory requirements for fitness for specific jobs

Methods of rehabilitation and redeployment at work

Factors effecting absence attributed to sickness

Assessment of fitness for work of older workers

Application of the stress or strain concept to disabled employees

Principles of ill health retirement

Disablement benefits

Section 2B, experience:

Clinical assessment of disability and fitness for work, both preplacement and after work related illness or injury

Assessment of impairment, disability, and handicap in relation to work

Clinical management in rehabilitation of disabled workers

Application of ergonomics to rehabilitation

Counsel employees regarding sickness absence

Management of workers with alcohol or drug problems

Monitoring sickness absence

Supervise training

Section 2C, competence:

Advise on impairment, disability, and handicap in relation to work

Advise on fitness for work in liaison with other professionals where appropriate

Advise on rehabilitation and redeployment

Advise managers, insurers, and employers on ill health retirement

Advise on sickness absence

Communications:

Section 3A, knowledge:

Organisation of occupational health services and role of statutory authorities

Ethical guidelines for communications with doctors, managers, and others

Role and organisation of other occupational health professionals

Organisation of other health services

Principles, techniques, and resources in communication

Organisation of occupational health services in other European countries

Section 3B, experience:

Preparation of written reports

Communications with other professionals about management of people

Oral presentations with audiovisual aids

Teamwork

Counselling

Participation in committees

Negotiating, influencing, and conflict resolution

Section 3C, competence:

Communicate with people of differing backgrounds and technical understanding

Organise and write reports

Make clear oral presentations with use of audiovisual aids

Read, write, and converse proficiently

Apply legislative and ethical requirements for confidentiality in communicating with other professionals about people

Participate effectively as a member of a committee

ems in italics were not in the first questionnaire.

the social sciences (SPSS). The knowledge, experience and competence subsections were treated separately. For each item in each of these subsections, the scores were averaged for all respondents and these are shown in table 3.
Results of analyses carried out to find if there was any variation in responses between people from different regions - for example, Eastern European respondents compared with those from Mediterranean countries-showed this to 


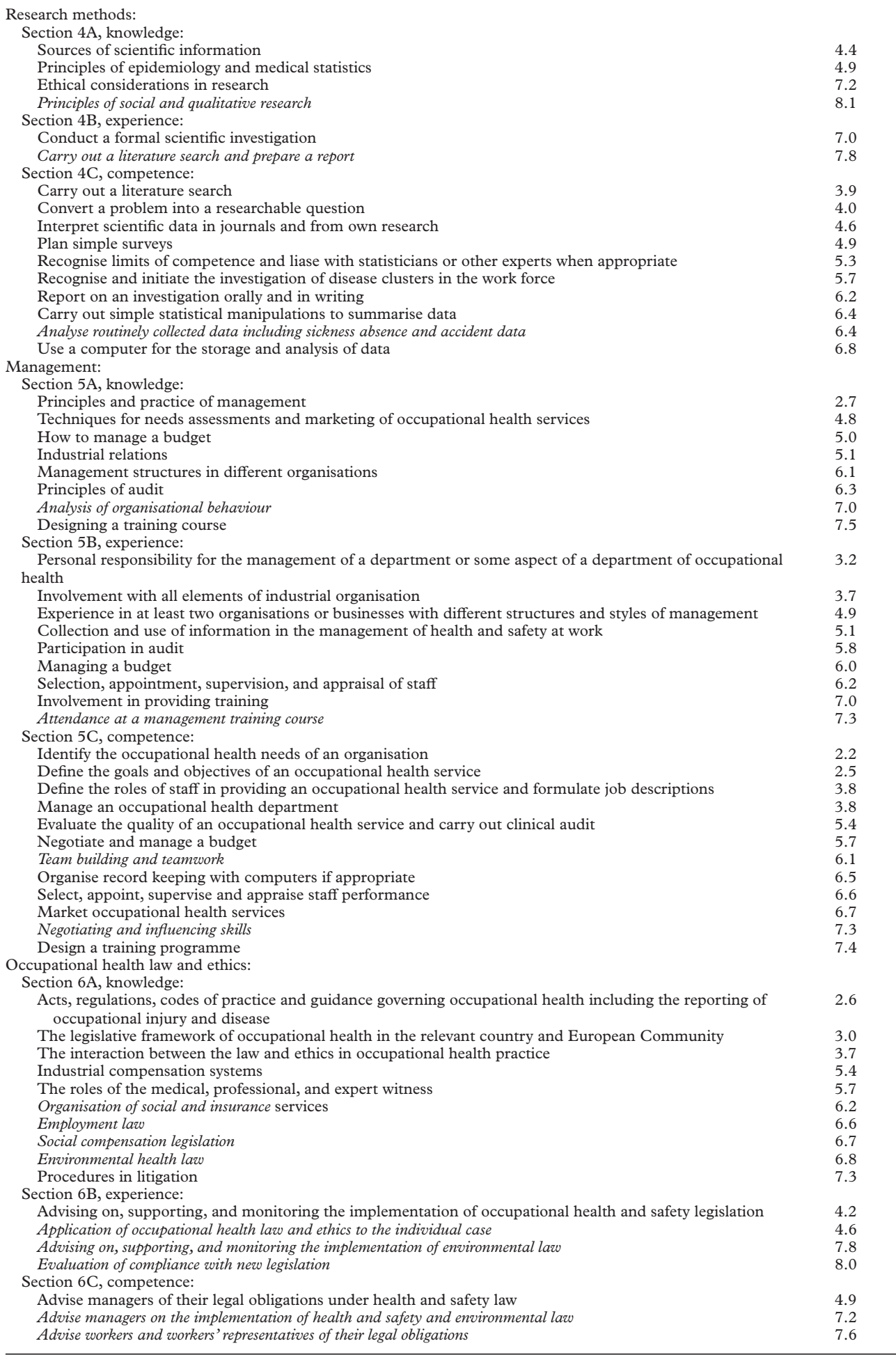

Items in italics were not in the first questionnaire.

be small in responses. Notable differences were that respondents from Belgium and Holland tended to rate the topics within the sections on assessment and disability more highly than respondents of other nationalities. Also, respondents from the United Kingdom and Ireland and the Nordic countries placed less importance on health promotion topics than the other national groupings. (Further information about these differences in the knowl- edge section is available from the authors.) Health promotion and management are recognised by WHO as increasingly important within the discipline; issues surrounding disability are of particular importance in some European countries; occupational hazards to health encompasses the traditional historical areas of occupational health. There was greater variation of mean scores for occupational hazards to health than the other subject areas. 


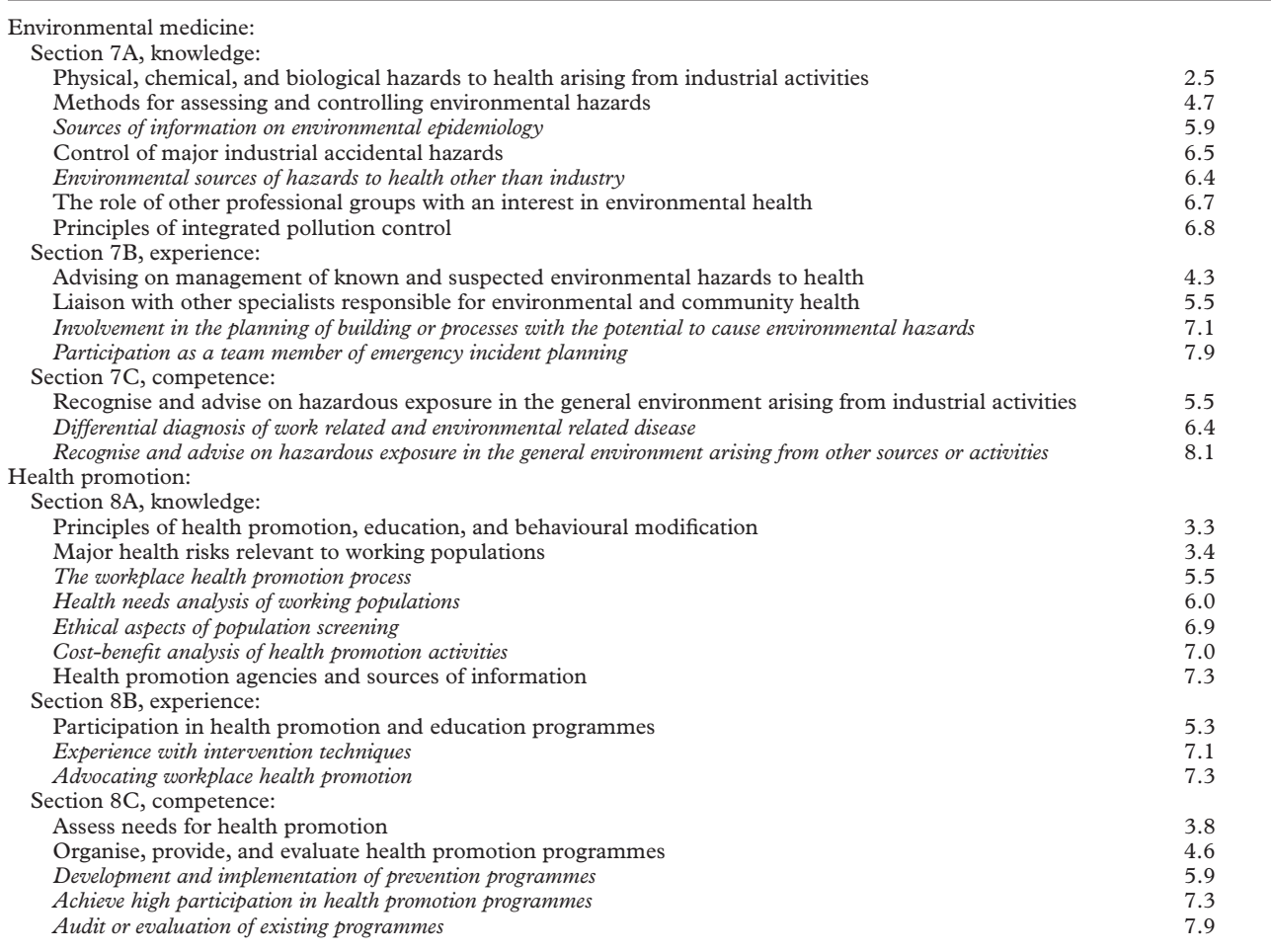

Items in italics were not in the first questionnaire.

Comparisons of the relative importance to respondents of the eight subject areas were made by with the Wilcoxon signed rank test. The results of these tests are displayed in tables 4,5 , and 6 .

These tables show that occupational hazards to health was almost always considered most important when compared with the other topic areas. Conversely, management was almost always considered least important. Environmental medicine was also considered to be significantly less important than most of the other topic areas. In all of these cases, this held true across the subsections of knowledge, experience, and competence. Health promotion showed greater variation across the subsections. In the knowledge subsection health promotion was rated as significantly more important than all other topics excepting occupational hazards to health. However, it was not rated above any of the other topic areas in the competence subsection.

ROUND 2

Of 87 questionnaires distributed in the second round, 70 completed questionnaires were received ( $80 \%$ response rate). These represented the same countries listed in table 2 with the addition of Poland, Greece, Croatia, and Luxembourg, and the were no returns from Bulgaria, Spain, Latvia, or the Slovak Republic. Items not included in the first round questionnaire but suggested by respondents are shown in italics in table 7 . Responses to the second questionnaire were analysed by summing the rank orders to produce a mean score for each item within each of the 24 sections. As some sections had as many as 12 items and some as few as two the mean scores were standardised to a 1-10 scale, to allow some comparison of the relative importance of items in different subsubsections. The standardised mean score also gives an indication of the consensus of opinion with the lowest scores indicating that many respondents gave this item high priority. High scores indicate that most respondents gave an item a low priority score. When a number of items within a section have similar scores this indicates that there was less consensus of opinion among the respondents.

In many of the sections there was a clear distinction between those items considered by the occupational physicians to be of greatest priority and those of less importance. For instance, within the section on occupational hazards to health, assessment of the working environment and surveillance for and diagnosis of occupational injury and disease were perceived to be of greatest importance. Those items relating to occupational safety - principles of occupational safety, safety training, and the use of safety equipmentwere, among others, considered important. In the section on management the most important issues were knowledge of the principles of management; experience of the management of an occupational health department; and competence in defining the needs for and objectives of an occupational health service and the roles of the staff. The ability to design and conduct training courses was of lower importance.

Interestingly, some of the items considered to be relatively less important to respondents included supervision and delivery of training in all aspects of occupational health, evaluation of health promotion programmes, and the principles of and advising on ill health retirement. 
Discussion

The many shortcomings of the Delphi technique in its application to prioritising areas of occupational medicine have been outlined elsewhere. ${ }^{5}{ }^{6}$ These include the requirement for respondents to prioritise lists of topic areas which they think are of equal importance. Also to avoid limiting the scope of the study a very large questionnaire may result. The time taken to complete the second questionnaire was remarked on by several respondents. However, the good response rate indicated the importance to the target group of conducting this exercise. Other comments made by respondents included the fact that some of the items can be interpreted in conceptually different ways according to the different traditions and ways of working in the European Community.

The list of competencies included in the questionnaire were taken from the training regulations of the United Kingdom Faculty of Occupational Medicine. These have evolved over several years and have been influenced by those produced by parallel organisations in North America and Australasia. This was reflected in the high level of concurrence of views as expressed by the occupational physicians who responded to the Delphi questionnaire and those non-European delegates who participated in the conference.

It seems that respondents maintain a traditional view of the competencies required of occupational physicians. With the diagnosis of occupational disease and risk assessment being rated the highest of the eight topic areas. Research was rated as the second most important topic and this is surprising given the relatively low number of active occupational research institutes in Europe. ${ }^{10}$ The topic area of law and ethics was third in importance rating reflecting the interest in ethical issues and the practice of occupational medicine highlighted in another recent survey. ${ }^{11}$ Relatively new topics such as health promotion and environmental medicine were not rated highly and it is of concern that the topic area assessment of disability which is such a significant component of occupational physicians' work was rated relatively low.

Of even greater concern is that management competencies were regarded as the least important by respondents. The importance of management skills were recognised by Donald Hunter who wrote that the occupational physician "must be so well trained that he will be invited to co-operate with managers, workers, engineers, chemists, and architects ... He should have an aptitude for administration . . . make the industrialist understand the risk to which his men are exposed". ${ }^{12}$

Donald Hunter, when describing the training of the doctor for industry, described the social aspects of the doctor's work as being the positive promotion of health and the prevention of disease. This Delphi survey has shown that respondents are still primarily disease focused and are lagging behind the evolving definition of occupational health.
Other subjects such as disability assessment, sickness absence analysis, and advice and competence in these areas were lowly ranked and yet these may be major components of an occupational physicians work.

Regulatory bodies such as the United Kingdom General Medical Council have stressed the importance of the behavioural skills of the doctor including team working, ${ }^{13}$ and yet in this survey these were generally lowly ranked.

The division of the eight subject areas into three further subsections-knowledge, experience, and competence-resulted in some anomalies. For example, in the section on research methods, respondents considered that it was very important that occupational physicians had competence in carrying out a literature search and converting a problem into a researchable question. However, having experience in carrying out a literature search and preparing a report was considered less important. This is likely to be a result of the experience subsection having only two items. Knowledge, together with experience, is the basis for identifying research questions and a discipline such as occupational health cannot evolve and meet changing needs without research. Experience of research, with publication and audit of other outcomes, can also lead to competencies. Therefore these three subsections are inextricably linked and this exercise may have created artificial distinctions within the subject areas.

What has been presented here is the consensus view of representatives of three major European Associations of occupational physicians. Within these associations, the academics are probably overrepresented (EASOM, 50\% of the UEMS). This might explain low ranking of the competencies required by occupational physicians in the workplace. Although there can be no dispute about the importance of occupational physicians maintaining and enhancing their clinical skills for the diagnosis and management of occupational disease and occupationally related ill health it would seem that respondents may have their priorities wrong for the 21 st century.

\section{The way forward}

REDEFINE COMPETENCIES

In undertaking this work it has become clear that there are opportunities to improve our definitions of our competencies. The changing definition of occupational health has lead to greater importance of health promotion and a reduction in the emphasis on occupational disease. The growing challenges of disability and work and the issues surrounding management skills are not currently being reflected in the priorities of the academic community within occupational medicine. Throughout Europe what tends to be written in the training documents such as those of the United Kingdom Faculty of Occupational Medicine are statements describing the topic area, rather than descriptions of the precise competency required. For example, there are differences in some of the relevant curriculum descriptors from the United Kingdom Faculty of Occupational Medicine and the appropriate section in 
the curriculum of the United States College of Occupational and Environmental Medicine. (These documents are available from the author.)

IDENTIFY THE REQUIREMENTS OF THE SOCIAL PARTNERS

In all cases, these curricula have been developed by medical professionals and therefore represent their perceptions of the health requirements of working populations. The views of the social partners-employers and employees - of these competencies have not been tested. The requirement to take into account the needs of the customer when planning occupational health services is well established. ${ }^{14}$ The arguments in favour of involving the customer groups in refining core competencies of occupational physicians are similar to those put forward by Harrington for research in occupational medicine. ${ }^{5}$ Industry needs a specific set of skills from the occupational physicians it pays to look after the health of the workforce. However, it is academe that defines the skills of the occupational physicians who will be employed by industry.

DELIVER THE COMPETENCIES

Those designing and delivering courses for trainee occupational physicians must ensure that there is appropriate emphasis on the com- petencies required in the workplace as well as those perceived to be important from an academic viewpoint.

1 Ramazzini B. Diseases of workers. New York: Hafner, 1964. 2 International Labor Conference, Occupational Health Services Convention 161. Geneva: International Labour Organisation, 1985

3 Lindstone HA, Turoff M, Lindstone HA, et al, editors. The Delphi method. Reading, Massachusetts: Addison-Wesley, 1975:3-16.

4 Moscovice I, Armstrong P, Shortell S, et al. Health services research for decision-makers: the use of the Delphi technique to determine health priorities. 7 Health Polit Policy Law 1977;2:388-410.

5 Harrington JM. Research priorities in occupational medicine: a survey of United Kingdom medical opinion by the Delphi technique. Occup Environ Med 1994;51:289-94.

6 Agius RM. Priorities for understanding and managing occupational allergy: a Delphi consensus. Clin Exp Allergy 1993;23:634-7.

7 van der Beek AJ, Frings-Dresen MHW, van Dijk FJH, et al. Priorities in occupational health research:a Delphi study in The Netherlands. Occup Environ Med 1997;54:504-10.

8 Faculty of Occupational Medicine of the Royal College of Physicians. Occupational medicine training record. London: FOM,RCP 1995:32-8.

9 Macdonald EB, Elder A, Ide C, eds. Requirements for occupational medicine training in Europe: the competencies. Glasgow: University of Glasgow, 1998 .

10 Harrington JM, Aw TC Occupational and environmental medicine in the United Kingdom. Int Arch Occup Environ Health 1996;68:69-74.

11 Salinas AA, Muto T, Rasanen K, et al. Structure and Strategy Task Group Final Report, Health Services Research and Evaluation. Amsterdam: International Commission on Occupational Health Scientific Committee, 1998

12 Hunter D. The diseases of occupations, 3rd ed. Health of the worker in the 20th century. London: Hodder and Stoughton, 1962;IV: 149-247.

13 General Medical Council Maintaining good medical practice. London: General Medical Council, 1998.

14 Macdonald EB. Audit and quality in occupational health. Occup Med 1992;42:7-11.

\section{Rejected manuscripts}

From February 1994, authors whose submitted articles are rejected will be advised of the decision and one copy of the article, together with any reviewer's comments, will be returned to them. The fournal will destroy remaining copies of the article but correspondence and reviewers' comments will be kept. 